\title{
OCCASIONAL ARCHAEOLOGICAL HUMAN SKELETAL REMAINS FROM LÄÄNEMAA, WESTERN ESTONIA
}

\author{
RAILi AllmäE \\ Institute of History, Tallinn University, Estonia
}

\begin{abstract}
During archaeological excavations in 2012 human skeletal remains were recovered from two sites in Läänemaa: four $16^{\text {th }}-17^{\text {th }}$ centuries skeletons from Ehte Street in the town of Haapsalu and two Late Iron Age $\left(12^{\text {th }}-13^{\text {th }} \mathrm{cc}\right.$. $)$ skeletons from the Maidla grave-field. The skeletal data from Läänemaa are scanty, thus anthropological analyses of these occasionally found remains were conducted and some characteristics of body build were calculated.
\end{abstract}

Keywords: skeletal remains, Western Estonia, body height, body weight, osteometry

\section{INTRODUCTION}

Large-scale archaeological investigations at the Maidla Iron Age grave-field have been conducted by the reseacher Mati Mandel during 1989-1990. The burial ground mostly contained human cremations from the $10^{\text {th }}-11^{\text {th }}$ centuries, but inhumations from the $12^{\text {th }}$ century to the beginning of the $13^{\text {th }}$ century were also present $[13 ; 3]$ During additional investigations at the Maidla grave-field in 2012 a double inhumation grave was found, it contained skeletal remains of the child at the age of 9 years and that of the woman at the age of 35-50 years [14]. All together with earlier skeletal finds from Maidla there are 9 skeletons available for anthropologial studies. In the present paper the results of body weight and stature calculations are presented and discussed in the light of other skeletal data of the $10^{\text {th }}-13^{\text {th }}$ centuries from Estonia. Archaeologial investigation in Ehte Street, the town of Haapsalu, were conducted in 2012 by the researcher Erki 
Russow. In the cultural layer unexpectedly human skeletal remains were found, the osteological material was forwarded for anthropological research. There are no former data of the cemetery in this location of the town of Haapsalu, the skeletons are probaly from the $16^{\text {th }}-17^{\text {th }}$ centuries [18]. Archaeological human skeletal remains have not been recovered from the town of Haapsalu so far. The $16^{\text {th }}-17^{\text {th }} \mathrm{cc}$. skeletons found in Ehte Street during construction works are the first ones from this part of Estonia to be analysed anthropologically. We have quite a representative collection of the metric data of the archaeological human remains of the $13^{\text {th }}-18^{\text {th }}$ centuries from other parts of Estonia. Thus some anthropological reconstructions based on the metric data of Ehte skeletons were conducted and compared to other Estonian ones. The results of anthropological analyses are presented in this paper.

\section{MATERIAL AND METHODS}

The osteological materials from the Maidla double grave arrived for the laboratory analysis as mixed bones. The bones of an adult and a child were separated for further analyses. Also, the skeletal materials collected from the Maidla grave field during earlier excavations (1989-1990) were included in the osteometric analysis, all together 9 skeletons from Maidla were available for study.

The osteological materials from Ehte Street (the town of Haapsalu) arrived for the laboratory analysis in two packages. The first package contained mainly the bones of lower extremities. The bones were sorted and reunited according to their anatomical congruity. The skeleton A consists of the bones of lower extremities, both preserved from femoral bones to phalanges of toes. The left femoral bone was fragmentary. The skeleton B consists also of the bones of lower extremities. The right lower extremity is preserved from the femoral bone to the phalanges of toes, however the left femoral is absent as well all foot bones despite the heel bone and the ankle bone. The second package also contained the skeletal remains of two individuals. The bones were sorted and in this case skeletons were reunited according to the skeletal age criteria as only the bones of juveniles were found. The skeleton $C$ was also only partially preserved: the bones of both lower extremities were found from the femoral bones to ankle and heel bones, only some metatarsal were present. The skeleton $\mathrm{D}$ was complete, the cranial and the post-cranial skeleton were both present. One complete and three partial skeletons were available for anthropological study. It must be noted that besides articulated human skeletal remains some human bones were 
found amongst commingled osteological material (two temporal bones, one lumbar vertebra, the right first rib, the left zygomatic bone, the $4^{\text {th }}$ cervical vertebra). Also, some animal bones were found as commonly in the cultural layers of medieval and early modern towns.

The biological age and the sex determinations of skeletons were conducted according to common criteria $[19,20,22,7]$. The metric criteria $[8,1,16,17]$ were used to determine the age of juveniles and the sex of adults in the cases of incomplete skeletons (for example, preserved only long bones of extremities). The long bones of extremities were measured according to Martin \& Saller [15], the right side was used if applicable. Measurements of the femoral bone (in $\mathrm{mm}$ ): F1 - the maximum length; F8 - the midshaft circumference; F20 - the circumference of the head; F18 - the superinferior breadth of the head; F10 the transversal breadth of the head; F21 - the distal epiphyseal breadth. Measurements of the tibial bone in $\mathrm{mm}$ : T1a - the maximum length; T3 - the proximal epiphyseal breadth, T6 - the distal epiphyseal breadth; T10 - the midshaft circumference; T10a - foramen nutricium circumference; T10b - the minimum circumference. The maximum lengths of long bones of upper extremities were also measured: H1 - humerus and R1 - radius. For children the diaphyseal lengths of long bones were measured if not stated otherwise. The stature of adults was calculated according to the formulas proposed by Ruff and coworkers [17], The northern formula was used for tibial stature calculations. Additionally the formulas of Trotter \& Gleser [21] were used, because these are widely used, despite of the fact that this model overesimates the stature and is therefore unsuitable for the Estonian population. The stature of children was calculated according to Ruff [16]. The body weight of adults was calculated according to Ruff and co-workers [17], and that of children and juveniles according to Ruff [16].

\section{RESULTS AND DISCUSSION}

\section{Skeletal remains from the Maidla grave-field}

The skeletal materials from Maidla grave-field have been analysed for age and sex determinations earlier $[3,13]$. The material under study contains skeletal remains of four women, two men and three children (Table 1). The mean body height of Maidla women was $156.9 \mathrm{~cm}$ and the body weight $60.9 \mathrm{~kg}$ on average; the body height and weight of men is $170.5 \mathrm{~cm}$ and $73.3 \mathrm{~kg}$ respectively. 


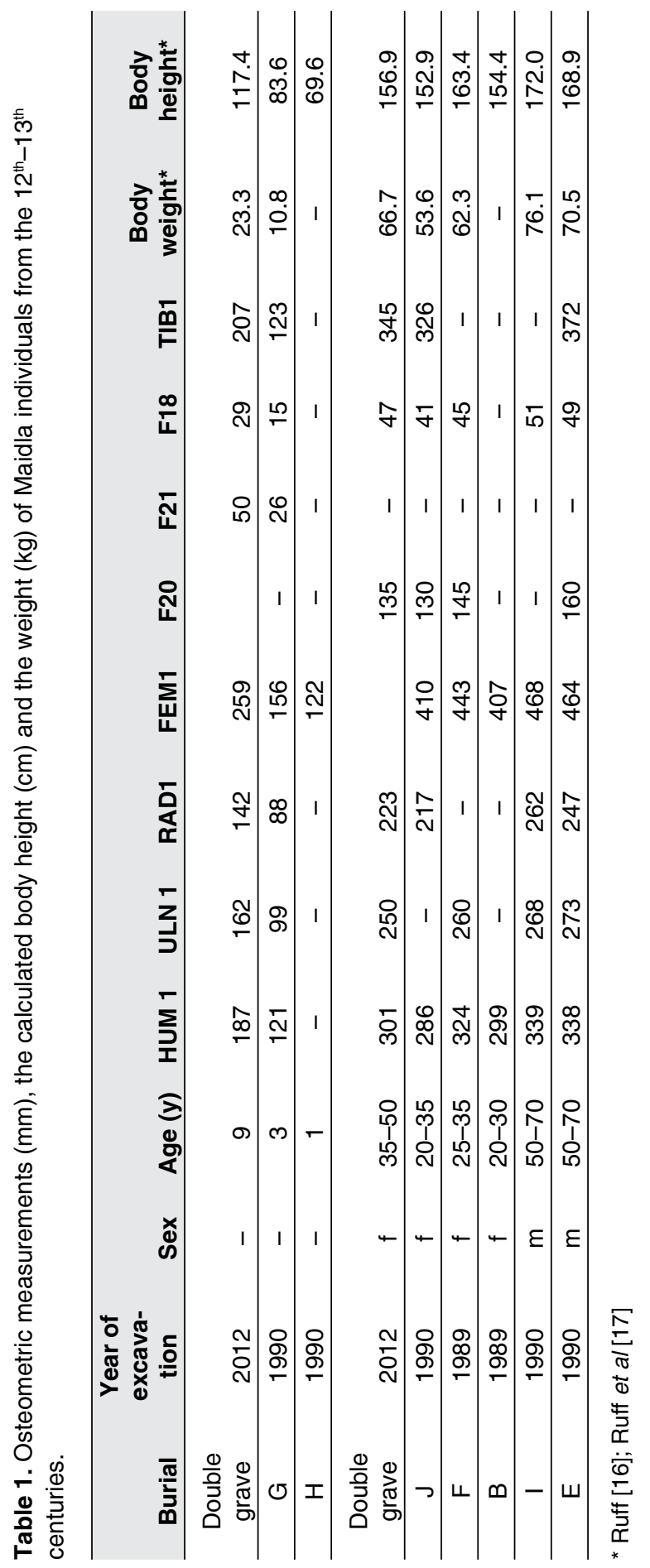


To compare the average stature of people from Maidla the equations proposed by Trotter \& Gleser [21] were also used (Table 2). At the beginning of the second millenium the Estonian population has been quite tall according to Heapost [10] , we may argue the same for the Maidla community - the body height of men $174.5 \mathrm{~cm}$, and that of women $159.9 \mathrm{~cm}$ (Table 2). The body height and weight of Maidla children is presented in Table 1. According to the data of the $14^{\text {th }}-18^{\text {th }}$ centuries the Estonian summarized sample of children's skeletal data [1] and the equations of Ruff [16], the average stature of the one-year-old child is $70.6 \mathrm{~cm}$, of the three-years-old child is $83.2 \mathrm{~cm}$ and of the nine-years-old child is $118.8 \mathrm{~cm}$. In the light of these data the children of the $12^{\text {th }}-13^{\text {th }} \mathrm{cc}$. at Maidla were of middle stature (Table 1).

Table 2. Calculated average body height $(\mathrm{cm})$ in the Late Iron Age Estonia $\left(11^{\text {th }}-13^{\text {th }} \mathrm{cc}\right.$.) according to Trotter \& Gleser [21]. Comparative data from Heapost [9, 10, 11, 12].

\begin{tabular}{ccc}
\hline Sample & Male & Female \\
\hline Maidla II & 174.5 & 159.9 \\
\hline Pada & 172.1 & 160.1 \\
\hline Siksälä & 175.8 & - \\
\hline Martna & 176.0 & - \\
\hline Küti & 174.6 & - \\
\hline Lindora & 175.3 & - \\
\hline Muhu & 173.0 & - \\
\hline Ida-Setumaa & 174.7 & 159.6 \\
\hline
\end{tabular}

\section{Skeletal remains from Ehte Street}

It is quite difficult to determine the biological age of on the basis of bones of lower extremities only (individuals A and B). Still some age ranges are proposed here. Both skeletons indicated epiphyseal unions completed for all the observed bones. The age is definitely above 25 years. On the other hand, the changes characteristic of osteoarthritis were observed on some foot bones of both skeletons. Thus we may presume that both individuals (A and B) died between the ages of 30-50 years.

Amongst commingled osteological material also some bones of adult individuals were found (two temporal bones, one lumbar vertebra, the right first rib, the left zygomatic bone, $4^{\text {th }}$ cervical vertebra). However, these bones are not reliably linked to the skeleton, which were found articulated on the site. Though, the temporal bones indicated, for example, anatomical differences in the size of the mastoid process, processus zygomaticus and the temporal line; so 
one of the bones may belong to a female and the other to a male skeleton. Both vertebras (lumbar, cervical) indicated small osteophytes at the edges of vertebral bodies, which is in good accordance with osteoarthritic changes on foot bones. We may speculate that during the earlier activities in the area the skeletal parts, which were relatively higher (skull, thorax, pelvis), in comparison with lower extremities were disturbed and moved to mixed layers. No further conclusion can be drawn from mixed human bones.

The age at death for the individual $\mathrm{C}$ was determined on the basis of the epiphyseal union. For all observable long bones the epiphyseal union was not completed, which means that the individual is probably under 15 years of age. Unfortunately the innominate bones - the most helpful skeletal part to determine if the age is above or below 15 years of age - were absent. The measurements of femoral and tibial bones of the individual $\mathrm{C}$ indicated the age above 12 years of age $[1,16]$. It should be mentioned that the means of diaphyseal lengths of European Americans are presented in Ruff [16].

The age at death of the individual $\mathrm{D}$ was determined on the basis of dental development [20]. The maximum lengths of tibial and femoral bones are also in accordance with the Estonian $14^{\text {th }}-18^{\text {th }} \mathrm{cc}$. summarised sample of 8-year-old children [1]. Slight cribra orbitalia was found on the skeleton $\mathrm{D}$. The condition linked to acquired chronic anaemia is commonly found in medieval and early modern samples of juvenile's skeletons. For example, in the Tääksi rural samples $44.1 \%$ and in the Pärnu urban sample $50 \%$ of juvenile skeletons indicated this condition $[2,4,6]$.

The skeletons of children were not sexed. The sex of an adult skeleton is quite difficult to determine without an innominate bone or skull. There is a possibility to determine the sex of the skeleton from metric data. Unfortunately here also difficulties arouse as adult skeletons indicated measurements, which are mainly in the range of uncertain sex estimation according to the data of Garmus and Jankauskas [8]. Finally the adult skeletons were sexed according to the metric data of the femoral head. The circumference of the femoral head (F20) is quite a reliable measurement for sexing skeleton on the basis of the bones of lowers extremities. The adult skeleton A is male (F20 $=160 \mathrm{~mm})$, and of B $(\mathrm{F} 20=145 \mathrm{~mm})$ is probably female (Table 3 ). 
Table 3. Osteometric data (mm)of skeletons from Ehte Street, Haapsalu.

\begin{tabular}{|c|c|c|c|c|c|}
\hline \multirow{2}{*}{$\begin{array}{l}\text { Measurements } \\
\text { according to }\end{array}$} & Ehte A & Ehte B & \multirow{2}{*}{$\begin{array}{l}\text { Measurements } \\
\text { according to }\end{array}$} & \multirow{2}{*}{$\begin{array}{c}\text { Ehte C } \\
\text { Juvenile }\end{array}$} & \multirow{2}{*}{$\begin{array}{c}\text { Ehte D } \\
\text { Juvenile }\end{array}$} \\
\hline & Adult & Adult & & & \\
\hline $\begin{array}{l}\text { Martin\&Saller } \\
\text { [15] }\end{array}$ & $\begin{array}{c}\sim 30-50 \\
\text { years }\end{array}$ & $\begin{array}{c}\sim 30-50 \\
\text { years }\end{array}$ & $\begin{array}{c}\text { Martin\&Saller } \\
{[15]}\end{array}$ & $12-15$ years & $7-9$ years \\
\hline Femoral & & & Femoral & & \\
\hline $\mathrm{F} 1$ & 431 & 427 & F1 & 377 & 240 \\
\hline F8 & 92 & 85 & F21 & 66 & 50 \\
\hline F20 & 160 & 145 & F18 & 40 & 26 \\
\hline F18 & 50 & 45 & Tibial & & \\
\hline F19 & 49 & 45 & T1d & 297 & 190 \\
\hline F21 & 82 & 79 & T1t & 333 & - \\
\hline \multicolumn{6}{|l|}{ Tibial } \\
\hline T1a & 339 & 335 & Humeral & & \\
\hline T3 & 75 & 71 & $\mathrm{H} 1$ & - & 178 \\
\hline T6 & 52 & 50 & Radial & & \\
\hline T10 & 87 & 84 & R1 & - & 133 \\
\hline T10a & 98 & 95 & Ulnar & & \\
\hline $\mathrm{T} 10 \mathrm{~b}$ & 77 & 76 & U1 & - & 146 \\
\hline
\end{tabular}

$\mathrm{d}$ - diaphyseal length: $\mathrm{t}$ - total length

According to anthropological analyses four people have been buried: $30-50$ years old male (A); 30-50 years old (probably) female (B); a child at the age of $12-15$ years (C) and a child (D) at the age of 8 years ( \pm 24 months).

The peculiarity of Ehte skeletons is that the tibial and femoral measurements of individuals $\mathrm{A}$ and $\mathrm{B}$ are quite similar, despite the dimensions of the femoral head (F18, F19, F20 - Table 3) and some minor discrepancies in the dimensions of the epiphyseal breadth of tibia (T3, T6 - Table 3). For $13^{\text {th }}-18^{\text {th }} \mathrm{cc}$. Estonian skeletal material the average male femoral length is $448.1 \mathrm{~mm}$ and that of female is $412.7 \mathrm{~mm}$; the tibial lengths are $357.94 \mathrm{~mm}$ and $332 \mathrm{~mm}$ respectively [5]. Thus, the femoral lengths of Ehte skeletons are between Estonian $\left(13^{\text {th }}-18^{\text {th }} \mathrm{cc}\right.$.) male and female averages. On the other hand, the tibial lengths of both skeletons are closer to the Estonian female average. There are two measurements, which allow us to determine the male sex for the skeleton $\mathrm{A}$. The circumference of the femoral head $-160 \mathrm{~mm}$; the dimension $160 \mathrm{~mm}$ and above is more characteristic of males according to Garmus and Jankauskas [8]; and the superinferior breadth of the femoral head $50 \mathrm{~mm}$. The superinferior breadth for 
the European male population is $48 \mathrm{~mm}$ on average [17]. The skeleton B indicates slightly smaller dimensions of long bones in comparison with $\mathrm{A}$, but not in all the measurements. The circumference of the femoral head $145 \mathrm{~mm}$ allows us to suggest the probable female sex, and the superinferior breadth of the femoral head $45 \mathrm{~mm}$ does not reliably support the female sex of $B$ individual.

The body stature and the weight were calculated for adult skeletons $\mathrm{A}$ and B (Table 4). Once again the stature calculations confirm relative shortness on the distal segment of lower extremities of Ehte adult individuals (shorter tibial stature). The calculated stature for a male (A) is modest, below the Estonian average; the stature of the individual $\mathrm{B}$ (probable female) is above the Estonian female average. The body weight of the individual $A$ is around $73 \mathrm{~kg}$, and that of $B$ around $62 \mathrm{~kg}$. Despite the formula used the difference in the body mass of individuals $\mathrm{A}$ and $\mathrm{B}$ is around $10-14 \mathrm{~kg}$ (Table 4). The stature of the individual C (12-15 years) is between $146.5-152.0 \mathrm{~cm}$, the calculated body weight is $39.6-43.8 \mathrm{~kg}$ (Table. 4 ).

Table 4. Reconstructed body height $(\mathrm{cm})$ and weight $(\mathrm{kg})$ of Ehte individuals, Haapsalu

\begin{tabular}{|c|c|c|c|c|c|c|}
\hline \multirow[b]{3}{*}{ Formula } & \multicolumn{3}{|c|}{ Method-Ruff et al [17] } & \multicolumn{3}{|c|}{ Method-Ruff [16] } \\
\hline & \multicolumn{3}{|c|}{ Stature from f'emoral bone (F1) } & & \multicolumn{2}{|c|}{$\begin{array}{l}\text { Stature from f'emoral } \\
\text { and tibial bones }\end{array}$} \\
\hline & Female & Male & Combined & & Ehte $\mathrm{C}$ & Ehte D \\
\hline Ehte A & 159.5 & 160.1 & 159.9 & F1d & 152.0 & 110.96 \\
\hline Ehte B & 158.4 & 159.0 & 158.8 & T1d & 146.5 & 110.66 \\
\hline $\begin{array}{l}\text { Estonian } \\
\text { average }\end{array}$ & 154.6 & 164.8 & & T1t & 149.8 & - \\
\hline & \multicolumn{3}{|c|}{ Stature from tibial bone (T1) } & & & \\
\hline Formula & Female & Male & Combined & & \multicolumn{2}{|c|}{$\begin{array}{l}\text { Stature from humeral and } \\
\text { radial bones }\end{array}$} \\
\hline Ehte A & 155.9 & 156.8 & 156.2 & $\mathrm{H} 1 \mathrm{~d}$ & - & 113.642 \\
\hline Ehte B & 154.8 & 155.6 & 155.0 & R1d & - & 114.318 \\
\hline \multirow[t]{2}{*}{$\begin{array}{l}\text { Estonian } \\
\text { average }\end{array}$} & 153.9 & 162.6 & & & & \\
\hline & \multicolumn{3}{|c|}{ Body weight from femoral bone (F18) } & & \multicolumn{2}{|c|}{$\begin{array}{l}\text { Body weight from femora } \\
\text { bone }\end{array}$} \\
\hline Formula & Female & Male & Combined & $\mathrm{F} 21$ & 39.6 & 21.2 \\
\hline Ehte A & 73.2 & 73.3 & 73.3 & F18 & 43.8 & 21.9 \\
\hline Ehte B & 62.3 & 59.3 & 61.8 & & & \\
\hline
\end{tabular}

$\mathrm{d}$ - diaphyseal length: $\mathrm{t}$ - total length 
Here also the tibial body stature is smaller than the femoral one, and it should be noted that the average stature of 12-15-year-old children from the $14^{\text {th }}-18^{\text {th }} \mathrm{cc}$ Estonia is somewhat shorter $-135.6 \mathrm{~cm}$. The body height of the individual D ( 8 years) is between $110.7-114.3 \mathrm{~cm}$ and the body weight $21.2-$ $21.9 \mathrm{~kg}$. The reconstructed stature is higher if calculated from the bones of upper extremities. In comparison with the average stature of 8 -year-old children from the Estonian $14^{\text {th }}-18^{\text {th }} \mathrm{cc}$. the 8 -year-old child from Haapsalu is of middle stature.

\section{CONCLUSIONS}

The mean body height of Maidla Late Iron Age women was $156.9 \mathrm{~cm}$, and body weight $60.9 \mathrm{~kg}$ on average; the body height and weight of men is $170.5 \mathrm{~cm}$ and $73.3 \mathrm{~kg}$ respectively. In comparison with other Iron Age skeletal data the stature of inhabitants of Maidla has also been quite high. The children of Maidla were of middle stature in comparison with the $14^{\text {th }}-18^{\text {th }}$ centuries Estonian children (summarised sample) Three partial skeletons and one complete skeleton from the $16^{\text {th }}$ to $17^{\text {th }}$ centuries were found during construction works in Ehte Street, the town of Haapsalu. Two partial skeletons (bones of lower extremities) belong to adults (A, B). The individual $\mathrm{A}$ is male, died at the age of 30 to 50 years. His stature was between $156.8-160.1 \mathrm{~cm}$ and the body weight around $73 \mathrm{~kg}$. The individual B is presumably female, died between the ages of 30 to 50 years of age. Her stature was $154.8-158.4 \mathrm{~cm}$ and the body weight approximately $62 \mathrm{~kg}$. The stature of the male was below and that of female is above average in comparison with the data of the Estonian $13^{\text {th }}-18^{\text {th }} \mathrm{cc}$. population. The juvenile individual $\mathrm{D}$ died at the age of $12-15$ years, the calculated body height was between $146.5-152.0 \mathrm{~cm}$ and the calculated body weight is 39.6$43.8 \mathrm{~kg}$. The juvenile individual $\mathrm{D}$ died at the age of 8 years; the calculated body height is between $110.7-114.3 \mathrm{~cm}$ and the body weight is around $21.2-21.9 \mathrm{~kg}$. In the light of the Estonian juvenile summarized sample from the $14^{\text {th }}-18^{\text {th }} \mathrm{cc}$, the 8 -year-old child of the $16^{\text {th }}-17^{\text {th }} \mathrm{cc}$. from the town of Haapsalu was of middle stature, and the 12-15-year-old child was of high stature. 


\section{ACKNOWLEDGEMENT}

The study was undertaken in the framework of the target funded research project of the Estonian Government (SF0130012s08).

\section{REFERENCES}

1. Allmäe R. (1998). Tääksi 14.-18. sajandi populatsiooni demograafiline analüüs ja kehapikkuse rekonstrueerimine. Muinasaja Teadus 5, 163-187.

2. Allmäe R. (1999). Dental and cranial pathologies in Tääksi $14^{\text {th }}-18^{\text {th }} \mathrm{cc}$. skeletal population. Papers On Anthropology, VIII, 9-14.

3. Allmäe R. (2003). Läänema 5.-13. sajandi kalmete antropoloogiline aines. Mandel, M. Läänemaa 5.-13. sajandi kalmed (Lisa 1). Eesti Ajaloomuuseum, Tallinn, 243-262.

4. Allmäe R., Limbo J. (2008). 16.-18. sajandi Pärnu garnisoni kalmistule maetute antropoloogiast. In: "Pärnumaa 1. köide. Loodus. Aeg. Inimene." Eesti Entsüklopeediakirjastus, Tallinn, 369-387.

5. Allmäe R. (2000). Stature and sexual dimorphism in Estonians of the $13^{\text {th }}-18^{\text {th }}$ centuries. Papers on Anthropology, IX, 11-23.

6. Allmäe R., Limbo J. (2010). Skeletal stress-markers in the Early Modern town of Pärnu, Estonia. Papers On Anthropology, XIX, 29-48.

7. Buikstra J. E., Ubelaker D. eds. (1994). Standards for Data Collection from Human Skeletal Remains: Proceedings of a Seminar at the Field Museum of Natural History. Arkansas Archaeological Survey Press, Fayetteville.

8. Garmus A., Jankauskas R. (1993). Method's of Persons Identification from the Skeleton in Lithuania. Medicina Legalis Baltica, 3-4, 5-21.

9. Heapost L. (2002). Saarlaste antropoloogiast. Saaremaa, Tallinn, 580-597.

10. Heapost L. (2003). Variation in stature in Estonia from $12^{\text {th }}$ to the $20^{\text {th }}$ centuries. Papers on Anthropology, XII, 51-61.

11. Heapost L. (2007). The cemetery of Siksälä: osteological and paleodemographical analysis. Laul, S., Valk, H. (Eds.). A Community at the Frontiers. Iron Age and Medieval Tallinn-Tartu: University of Tartu, 213-236.

12. Heapost L. (2009). Osteometric data and the stature of the population of Eastern Setumaa (Pechory and Izborsk districts) in the $11^{\text {th }}-15^{\text {th }}$ century. Papers on Anthropology, XVIII, 122-143.

13. Mandel M. (2003). Läänemaa 5.-13. sajandi kalmed. Eesti Ajaloomuuseum, Tallinn, 1-242.

14. Mandel M., Allmäe R. (2013). Forschungs -und Errichtungsarbeiten Im Gräberfeld $\mathrm{Zu}$ Maidla. Arheoloogilised välitööd Eestis = Archeological fieldwork in Estonia 2012. In print.

15. Martin R., Saller K. (1957). Lehrbuch der Anthropologie, I-III. Stuttgart. 
16. Ruff C. D. (2007). Body Size Prediction From Juvenile Skeletal Remains. American Journal of Physical Anthropology, 133, 698-716.

17. Ruff C. B., Holt B. M., Niskanen M., Sladék V., Berner M., Garofalo E., Garvin H.M., Hora M., Maijanen H., Niinimäki S., Salo K., Schuplerová E., Tompkins D. (2012). Stature and Body Mass Estimation From Skeletal Remains in the European Holocene. American Journal of Physical Anthropology, 148, 601-617.

18. Russow E., Allmäe R. (2013). From a Suburban Pasture to the Urban Cemetery. Recent Fieldwork in North-Western Corner of Medieval Haapsalu. Arheoloogilised välitööd Eestis = Archeological fieldwork in Estonia 2012. In print.

19. Schinö H. R. (1979). Lehrbuch der Röntgendiagnostik, Bd.II, Teil 1. Skelett. Hrsg. von H. R. Schinö et al. Stuttgart, 1979.

20. Ubelaker D. H. (1989). Human Skeletal Remains: Excavation, Analysis, Interpretation. $2^{\text {nd }}$ ed. Taraxacum, Washington, D.C.

21. Trotter M., Gleser G. C. (1952). Estimation of stature from long bones of American Whites and Negroes. American Journal of Physical Anthropology, 16:1, 463-514.

22. WEA 1980=Recommendations (1980). Workshop of European anthropologists, "Recommendations for Age and Sex Diagnoses of Skeletons." Journal of Human Evolution, 9, 517-549.

\section{Address for correspondence:}

Raili Allmäe

Department of Archeobiology and Ancient Technology

Institute of History

Tallinn University

Rüütli 6, Tallinn 10130, Estonia

E-mail: raili.allmae@tlu.ee 